\title{
ナノ構造ポリマー研究会 in Yonezawa
}

ナノ構造ポリマー研究協会が, 2002 年 6 月 25 日に $\mathrm{NPO}$ (特定非営利活動法人) として認証され, 同年 7 月 3 日に登記が完了した。今後, (1)ナノ構造ポリマーに関する 情報共有のために研究会, 講演会, 見学会などの技術交流 会を開催，(2)ナノ構造ポリマーに関する国際セミナーの開 催, (3)ノ構造ポリマーに関する最新技術の進渉状況の発 信, を柱として活動していく. 今回, ナノ構造ポリマー研 究協会の発足を記念して, ‘ナノ構造ポリマー研究会 in

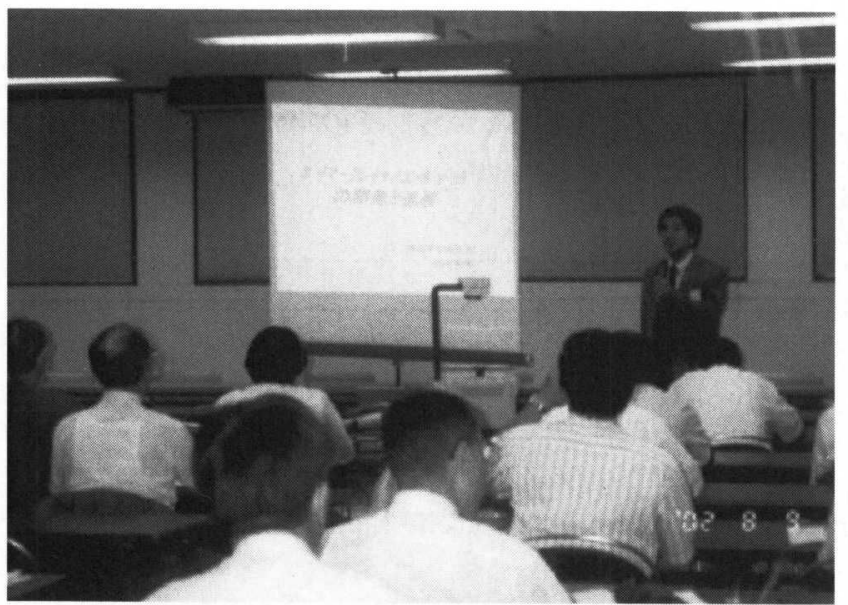

写真 1 日杵氏（豊田中央研究所）の講演
Yonezawa' が米沢市内工業団地 (夢想工房), 山形大学 工学部で開催された (2002 年 8 月 9 日から 10 日). 参加 者は 50 名で, 大盛況であった. 近年, ナノレベルでの構 造を持つポリマーを中心に新材料への期待が高まっている 状況を踏まえ, 今回のセミナーでは, 本分野における最先 端技術の討論およびベンチャー企業の立ち上げを中心議題 として企画された。

初日は, 2 件の講演（1)山形大学 小滝雅也氏：「高分 子材料のスクラッチ特性」, (2)豊田中央研究所 臼杵有光 氏：「ポリマーノクレイナノコンポジットの開発と発展」) と夢想工房の見学が行われた. (1)「高分子材料のスクラッ 千特性評価」では, 数種類の高分子材料について, スクラッ チ特性評価を試みた成果が報告された。本研究は, 経済産 業省委託事業「高分子の破壊判別手法の標準化」の一環と して行われている. (2)「ポリマー/クレイナノコンポジッ トの開発と進展」では, その歴史, 合成, 特徴が説明され た. 特に, ナイロン/クレイハイブリッドの開発経緯とそ の技術を PP など他の樹脂へ応用した例, さらにゴム (EPDM) やエラストマー（SEBS）に展開した例が紹介 された. 講演後の質疑応答では, 活発な議論がなされ, ナ ノ構造ポリマーへの関心の高さが伺えた。

その後, 夢想工房を見学した。夢想工房は, プレハブ住 宅の生産拠点の跡地（旧中央研究所 2 万坪と生産工場 20

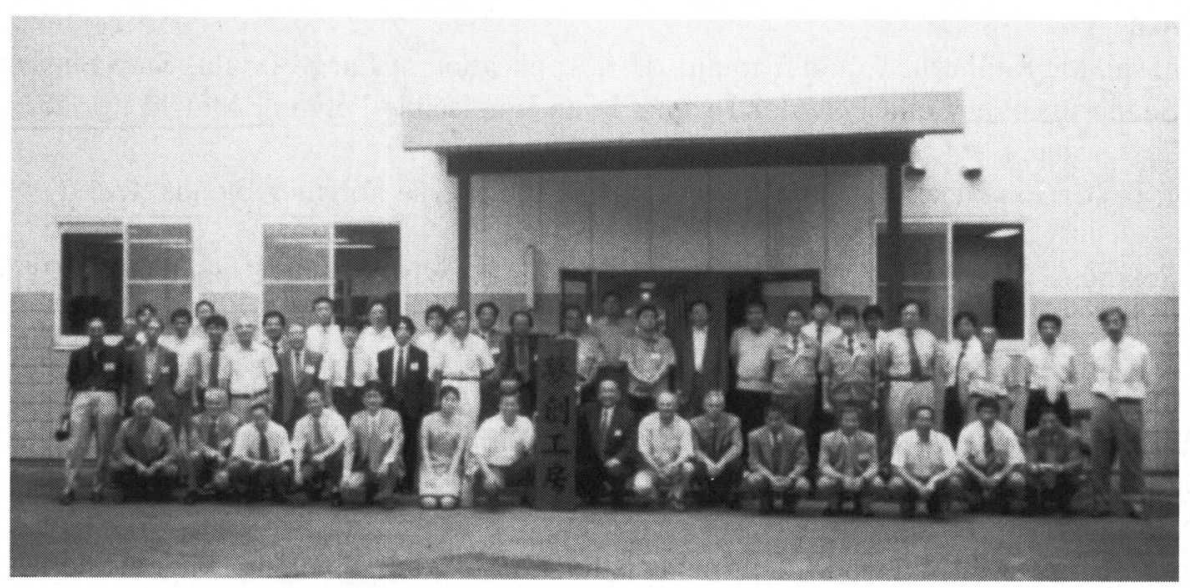

写真 2 セミナー参加者の記念写真（夢想工房前にて）

Kano, Yoshihisa

古河電気工業(侏) 環境・エネルギー研究所

平塚市東八幡 5-1-9（テ 254-0016）

2002.9.2 受理 


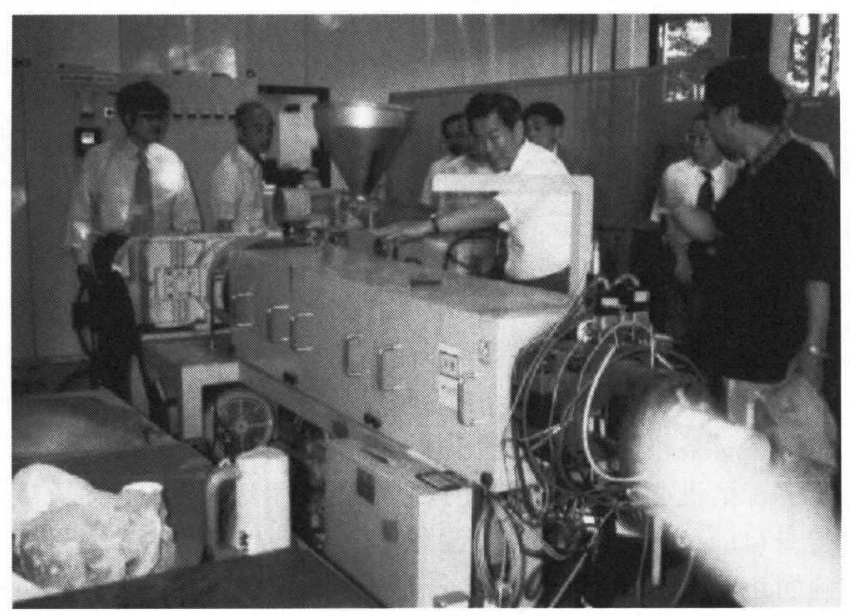

写真 3 夢想工房内の押出機

万坪の一部) であり, 現在は山形大学の井上 隆教授らが 開発したアスワン（廃ペットボトルから成形されるプラス トマー）の成形加工と生産ラインとして活用していく、ア スワンとは, ペットボトルを砕いたフレークに, 数種類の プラスチックとゴムを配合し, 化学反応させながら混練に より調製した熱可塑性プラストマーである. 針金のように 折り曲げたり，プレス成形できるなど多様な特性を有して おり, 携帯電話のボディーやファッション素材への応用が 期待されている. ラボ機から生産ラインに使用できる押出 機までの非常に充実した設備で, 近い将来, アスワンの生 産ラインの拠点としても期待できる.

二日目は, 山形大学のベンチャー・ビジネス・ラボラト リーを訪問し, その活動や研究設備を見学した. 概要と活

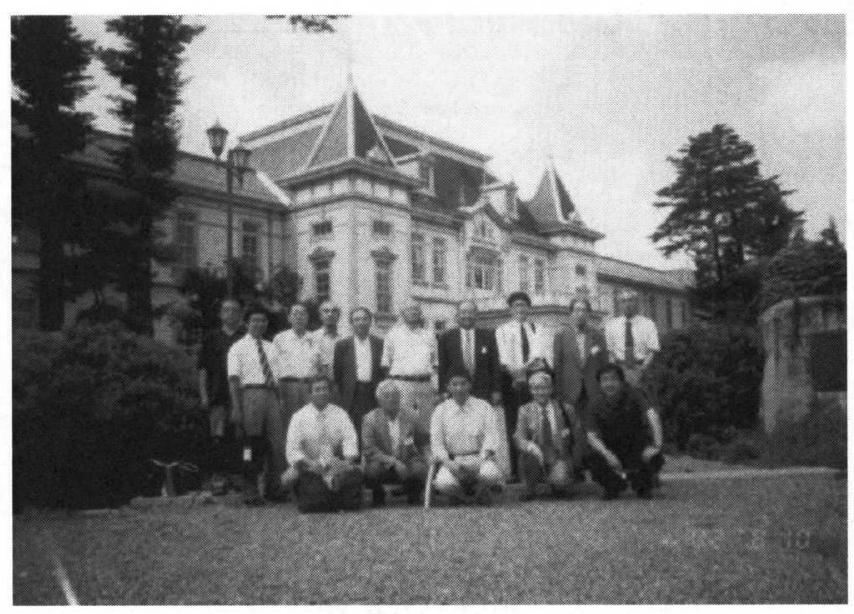

写真 4 山形大学工学部旧校舎と参加者

動が山形大学の栗山 卓先生から紹介された。その後, 地 域共同研究センターおよびベンチャー・ビジネス・ラボラ トリーの施設を見学した。 なお, 初日の夜, 小野川温泉の 日本旅館寿宝園を会場として, 交流懇親会が行われた。和 やかな雲囲気で時間が経過し, 夜遅くまでナノ構造ポリ マーの話題を中心に懇談が続けられた。 参加者メンバー間 の交流が深まったものと思われる.今後, ナノ構造ポリマー 研究協会では, ‘ナノ構造ポリマー研究会 in Yonezawa' のような 1 泊 2 日でのセミナーを毎年開催する予定である。 最後に，本分野で既にご活躍の研究者・技術者のみならず, ナノ構造ポリマーにご興味を抱いている多くの方々が参加 され，さらに活発な活動となることを期待したい.

\section{文献 抄 録}

\section{(3)}

\section{Polymer Technology}

- Vol.19 (2000), No.4

Nield, S. A., Tzoganakis, C. and Budman, H. M.: Chemical Modification of Low Density Polyethylene Through Reactive Extrusion : Part I : Process Development and Product Characterization（p.237）

Evstatiev, M., Fakirov, S., Bechtold, G. and Friedrich, K.: Structure-Property Relationships of Injection- and Compression-Molded Microfibrillar-Reinforced PET/PA-6 Composites（p.249）

Covas, J. A., Machado, A. V. and Van Duin, M. : Rheology of PA-6/EPM/EPM-g-MA Blends Along a Twin-Screw Extruder (p.260)

Zatloukal, M., Vleck, J., Tzoganakis, C. and Dobbie, T.: Computation of the Linear Viscoelastic Relaxation Spectrum from Capillary Viscosity Data (p.277)

Qian, B. and Gogos, C. G. ; The Importance of Plastic Energy Dissipation (PED) to the Heating and Melting of Polymer Particulates in Intermeshing Co-Rotating Twin-Screw Extruders (p. 287)

Lee, M., Tzoganakis, C. and Park, C. B. : Effects of Supercritical $\mathrm{CO}_{2}$ on the Viscosity and Morphology of Polymer Blends (p.300)

Kravtsov, A., Brünig, H., Zhandarov, S. and Beyreuther, R. : The Electret Effect in Polypropylene Fibers Treated in a Corona Discharge (p.312) 